\title{
The role of dendritic cell subsets and innate immunity in the pathogenesis of type 1 diabetes and other autoimmune diseases
}

\section{OPEN ACCESS}

Edited by:

Daniel Hawiger,

Saint Louis University, USA

Reviewed by:

Muriel Moser,

Université Libre de Bruxelles, Belgium

Diana Dudziak,

University Hospital of Erlangen,

Germany

Karsten Kretschmer,

CRTD/DFG-Center for Regenerative

Therapies Dresden, Germany

${ }^{*}$ Correspondence:

Kristin V. Tarbell,

Diabetes, Endocrinology, and Obesity

Branch, Immune Tolerance Section,

National Institute of Diabetes and

Digestive and Kidney Diseases, $\mathrm{NIH}$,

Building 10 Room 5-5940, 9000

Rockville Pike, Bethesda, MD 20892,

USA

tarbellk@niddk.nih.gov

tPresent address: Jeffrey D. Price,

Nebraska Center for Virology,

University of Nebraska-Lincoln, Lincoln, NE, USA

Specialty section:

This article was submitted to Immunological Tolerance, a section of the journal Frontiers in Immunology

Received: 10 April 2015

Accepted: 18 May 2015

Published: 15 June 2015

Citation:

Price JD and Tarbell KV (2015) The

role of dendritic cell subsets and

innate immunity in the pathogenesis

of type 1 diabetes and other

autoimmune diseases.

Front. Immunol. 6:288.

doi: 10.3389/fimmu.2015.00288

\author{
Jeffrey D. Price ${ }^{\dagger}$ and Kristin V. Tarbell ${ }^{*}$
}

Diabetes, Endocrinology, and Obesity Branch, Immune Tolerance Section, National Institute of Diabetes and Digestive and Kidney Diseases, National Institutes of Health, Bethesda, MD, USA

Dendritic cells (DCs) are key antigen-presenting cells that have an important role in autoimmune pathogenesis. DCs control both steady-state $T$ cell tolerance and activation of pathogenic responses. The balance between these two outcomes depends on several factors, including genetic susceptibility, environmental signals that stimulate varied innate responses, and which DC subset is presenting antigen. Although the specific DC phenotype can diverge depending on the tissue location and context, there are four main subsets identified in both mouse and human: conventional CDC1 and cDC2, plasmacytoid DCs, and monocyte-derived DCs. In this review, we will discuss the role of these subsets in autoimmune pathogenesis and regulation, as well as the genetic and environmental signals that influence their function. Specific topics to be addressed include impact of susceptibility loci on DC subsets, alterations in DC subset development, the role of infection- and host-derived innate inflammatory signals, and the role of the intestinal microbiota on DC phenotype. The effects of these various signals on disease progression and the relative effects of DC subset composition and maturation level of DCs will be examined. These areas will be explored using examples from several autoimmune diseases but will focus mainly on type 1 diabetes.

Keywords: dendritic cells, autoimmunity, type 1 diabetes, innate immunity, $\mathrm{T}$ cell tolerance, antigen presentation

\section{Introduction}

Dendritic cells (DCs) play a vital role in host immunity by inducing innate inflammatory responses to pathogens, efficiently priming naïve $\mathrm{T}$ cells, activating memory $\mathrm{T}$ cells, and promoting $\mathrm{B}$ cell activation. However, DCs are also integral in maintaining steady-state immune homeostasis by continually presenting tissue-derived self-antigens to $\mathrm{CD} 4^{+}$and $\mathrm{CD} 8^{+} \mathrm{T}$ cells in the absence of inflammatory signals, leading to tolerance against those self-antigens. DCs can affect induction of both immunity and tolerance in several ways, including at the level of DC development, the relative composition of DC subsets, and the extent of DC maturation.

Autoimmune diseases occur when autoreactive $\mathrm{T}$ and $\mathrm{B}$ cells escape negative selection in the thymus and bone marrow, respectively, followed by breaks in peripheral tolerance mechanisms that disrupt immune system homeostasis. Antigen-presenting cells (APCs), including DCs, play a central role both in the initial thymic selection of the $\mathrm{T}$ cell repertoire and in maintaining peripheral $\mathrm{T}$ cell tolerance for autoreactive cells. DCs affect autoimmune diseases including $\mathrm{T}$ cell-centric diseases 
such as type 1 diabetes (T1D) and multiple sclerosis (MS) and diseases thought to be mediated by B cells and antibodies, such as systemic lupus erythematosus (SLE). For example, in nonobese diabetic (NOD) mice, a model for T1D, DCs can modify pathogenesis by appearing in pancreatic islets early in life and presenting self-peptides to autoreactive $\mathrm{T}$ cells in the pancreatic lymph node (1). Thus, altering DC number or phenotype can affect disease progression (2).

Early interplay between innate immunity and target tissues is often a hallmark of autoimmune disease $(3,4)$. The question of DC effects on autoimmune disease centers on the possibility that DCs could either induce or suppress autoreactive $\mathrm{T}$ cell responses and focuses on DC proteins that would affect those interactions. Initial studies of DC ablation showed that decreased DCs-induced autoimmunity because of an inability to maintain Tregs (5), yet other studies have demonstrated that a loss of DCs actually decreased disease severity by blocking activation of pathogenic cells $(6,7)$. In both autoimmune patients and murine models of autoimmunity, DCs exhibit alterations in phenotype or function that could be due to underlying genetic defects or the chronic inflammatory environment, and can affect both the initiation of disease and later failure of tolerance mechanisms that lead to tissue destruction such as loss of insulin-producing beta cells in T1D (Figure 1). Understanding the balance between the regulatory and pathogenic role of DCs is important for learning how to block autoimmunity in the clinic.

The lack of uniform nomenclature and definitions of particular DC populations can make comparison of data from different groups difficult. Therefore, it is helpful to use the recent simplified nomenclature of $\mathrm{cDC} 1, \mathrm{cDC} 2, \mathrm{pDC}$, and monocyte-derived cells (Figure 2) that is based primarily on ontogeny with further specialization depending on location, and highlights the match between mouse and human DC subsets (16). Under this system, steady-state DCs can be broken down into three main subsets based on developmental origin, surface markers, and function: plasmacytoid DCs (pDCs) that can produce high levels of type 1 interferons (IFN), and two conventional DC (cDC) subsets, cross-presenting cDC1 that expresses CD8 or CD103 in mice and $\mathrm{CDC} 2$ that express $\mathrm{CD} 11 \mathrm{~b}^{+}$and efficiently stimulate $\mathrm{CD}^{+}{ }^{+} \mathrm{T}$ cell proliferation (Table 1). In humans, $\mathrm{cDC} 1$ expresses BDCA3 and $\mathrm{cDC} 2$ express $\operatorname{BDCA} 1(17,18)$. pDCs express BST2 and Siglec-H in mice and BDCA2 in humans $(19,20)$. Further specialization of these DC subsets occurs in peripheral tissues. Separate from these steady-state DC subsets, monocytes that are activated to express MHC II share some functional features with cDCs, such as expression of CD11b, but their overall gene expression patterns are much closer to monocytes than any DC subset $(21,22)$. Regardless, much of the literature refers to these monocyte-derived cells as DCs. Because GM-CSF can induce development of these monocytederived DCs in vitro from both human and mouse monocytes, this is a popular model, but it is important to recognize that they are a separate entity from cDCs. This review describes recent advances in our knowledge of the differential roles of particular DC subsets and activated monocytes for tolerance induction.

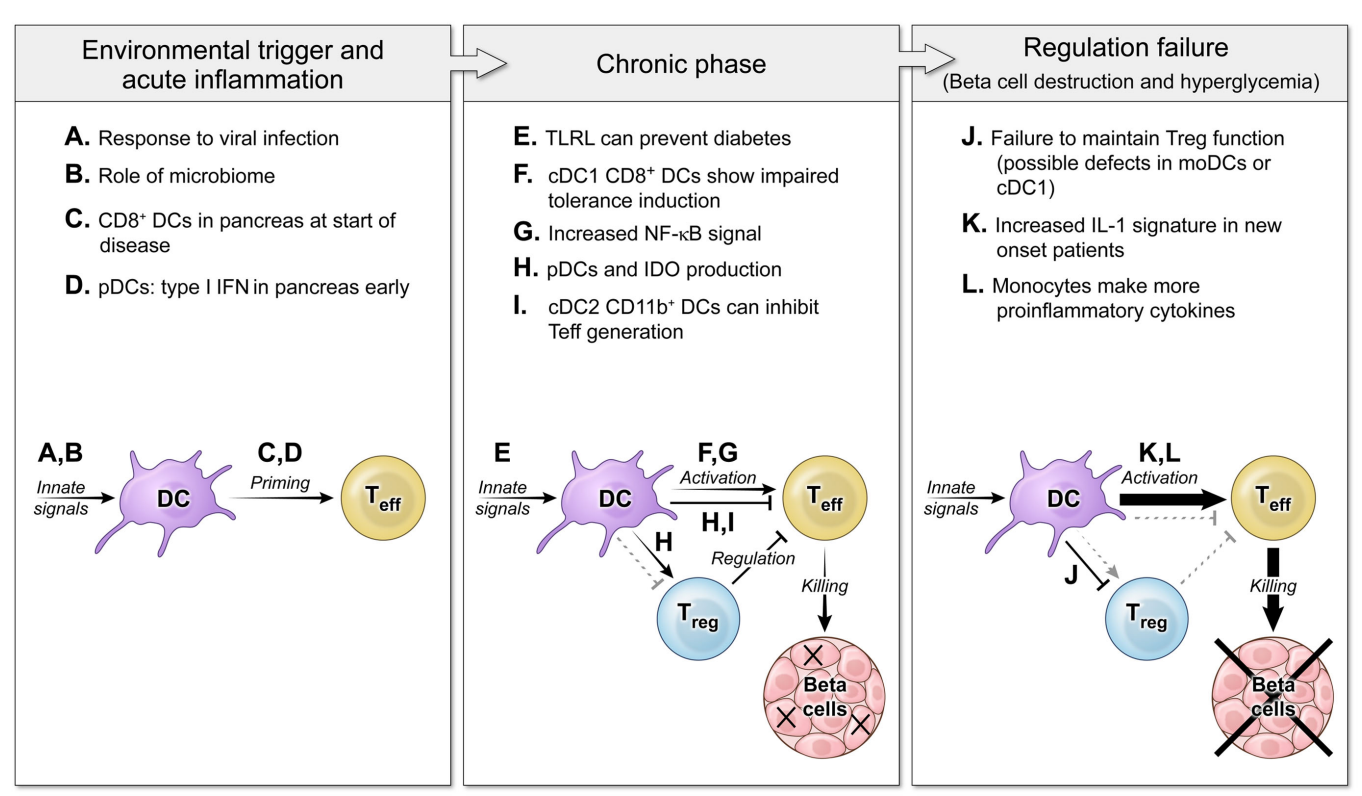

FIGURE 1 | The roles of DCs in autoimmune diabetes pathogenesis at several disease stages. Three main phases of autoimmune pathogenesis occur in type 1 diabetes (with parallel stages found in other autoimmune diseases). Although defined by changes in T cell responses, these stages are controlled by DCs and innate immunity. First, an innate environmental trigger contributes to loss of peripheral tolerance and priming of autoreactive $T$ cells (8-11). These innate signals can be infectious (A) or endogenous (B), and the result is to activate DC populations that stimulate self-specific T cells (C,D). Next, in the chronic phase of the disease, autoimmunity is tenuously balanced with regulation $(12,13)$. DCs continue to respond to innate stimuli, but now some TLRL block disease (E). DCs interact with effector $T$ cells and regulatory $T$ cells to mediate both activating $(\mathbf{F}, \mathbf{G})$ and regulating interactions $(\mathbf{H}, \mathbf{I})$. Finally, the balance tips to a failure of tolerance and tissue destruction mediated by non-productive interactions between DCs and Tregs $(\mathbf{J})$ and DCs giving increased activating signals to Teff $(\mathbf{K}, \mathbf{L})(14,15)$. 


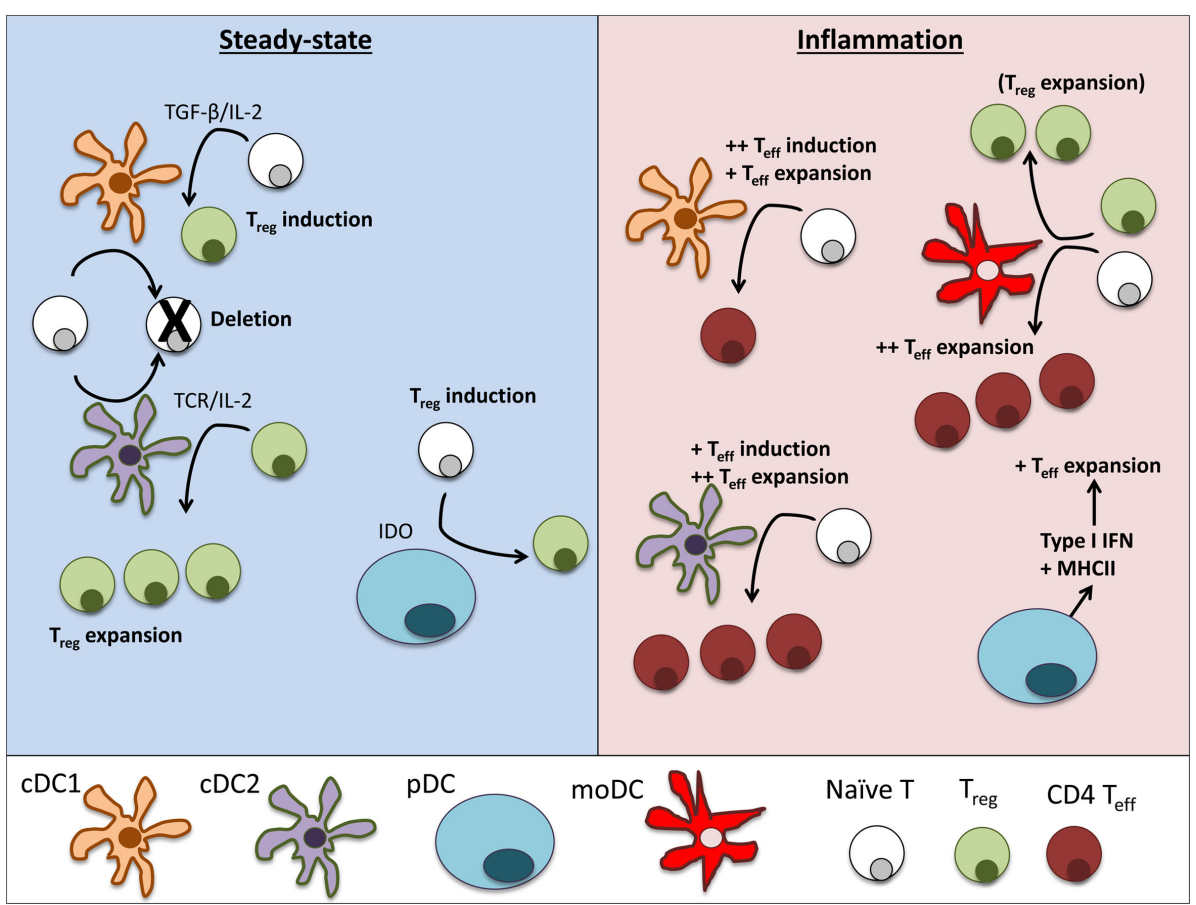

FIGURE 2 | Dendritic cell subsets perform particular functions in steady-state and inflammation. In steady-state tissues (left panel), lymphoid-resident CDC1 and CDC2 bearing self-antigen can both suboptimally stimulate naïve $\mathrm{CD}^{+}{ }^{+}$and $\mathrm{CD}^{+}{ }^{+} \mathrm{T}$ cells and cause deletional tolerance of autoreactive cells. A subset of naïve CD4 ${ }^{+} T$ cells that are stimulated by $C D C 1$ will encounter TGF- $\beta$ on the DC and induce Foxp3 and become a Treg. If a Treg is stimulated by cDC2, it will clonally expand that population of Tregs. pDCs have limited capacity to stimulate $\mathrm{CD}^{+}{ }^{+} \mathrm{T}$ cells directly due to low $\mathrm{MHCll}$ and costimulatory molecule levels. Under certain conditions, pDCs have been demonstrated to produce IDO and induce Treg generation. During inflammation (right panel), cDCs mature and can stimulate effector $\mathrm{T}$ cell responses, including Th1 and Th17 cells often associated with autoimmune disease. cDC1 can induce strong Th1 responses from naïve cells and cDC2 are more efficient in expanding CD4 Teff. pDCs respond to inflammation by secreting large amounts of type I interferons that can significantly alter the pathogenesis of autoimmune diseases. Inflamed pDCs also upregulate $\mathrm{MHCll}$, allowing efficient antigen presentation. moDCs mature from circulating monocytes $\left(\mathrm{Ly}^{+}{ }^{+}\right.$in mice, CD14 ${ }^{+}$ in humans) as they enter inflamed tissues. moDCs are adept at inducing Th1 responses via secretion of IL-12, but can also expand Tregs in some circumstances.

\section{The Role of Specific DC Subsets in Autoimmunity}

\section{Conventional DCs: $\mathrm{CD}^{+} \mathrm{cDC}^{\mathrm{C}}$ and $\mathrm{CD} 11 \mathrm{~b}^{+}$ DCIR2 $^{+}$cDC2}

The different roles of specific DC subsets in eliciting autoimmune pathogenic responses versus tolerance induction are likely to be important for successful immunotherapy. $\mathrm{CDC} 1 \mathrm{~s}$ and $\mathrm{cDC} 2 \mathrm{~s}$ are primarily located in distinct anatomical locations in lymphoid tissues and process and present antigen on MHCI and MHCII differently, and thus cause different stimulation of $\mathrm{CD}^{+}$and $\mathrm{CD}^{+} \mathrm{T}$ cells (29). Ultimately, cDC1s efficiently cross-present antigens to $\mathrm{CD}^{+} \mathrm{T}$ cells, while $\mathrm{cDC} 2 \mathrm{~s}$ more efficiently stimulate $\mathrm{CD}^{+} \mathrm{T}$ cells, although either $\mathrm{DC}$ subset can stimulate both $\mathrm{T}$ cell subsets $(26,29)$. Using antigen-encoding chimeric antibodies that bind lectins differentially expressed by DC subsets to deliver antigen in vivo to specific DC subsets is one valuable tool that has made it possible to compare the $\mathrm{T}$ cell responses elicited in vivo by particular DC subsets. In mice, anti-DEC-205 antibodies have been used to efficiently target antigen to lymphoid-resident $\mathrm{CD}{ }^{+}{ }^{-} \mathrm{DCs}$ and migratory $\mathrm{CD} 103^{+}$ cDC1s $(34,35)$. In non-autoimmune-prone mice, chimeric antiDEC-205 antibodies elicit tolerance induction in both $\mathrm{CD}^{+}$and
$\mathrm{CD}^{+} \mathrm{T}$ cells if no other inflammatory signals are added (i.e., steady-state tolerance), but can induce strong antigen-specific immunity if given with toll-like receptor (TLR) ligands and anti-CD40 $(34,36)$. Although less-studied, anti-DCIR2 has likewise been utilized to demonstrate that $\mathrm{CDC} 2 \mathrm{~s}$ are also tolerogenic in vivo for both $\mathrm{T}$ and $\mathrm{B}$ cell responses under steady-state conditions $(29,37)$.

In autoimmune-prone NOD mice, DEC-205 ${ }^{+} \mathrm{cDC} 1 \mathrm{~s}$ are able to induce tolerance in autoreactive $\mathrm{CD} 8^{+} \mathrm{T}$ cells $(27)$ but antigen presented by these DCs stimulate Th1 responses in autoreactive $\mathrm{CD} 4^{+} \mathrm{T}$ cells even without exogenous maturation signals. This defect in steady-state tolerance is corrected by inhibition of CD40/CD40L interactions (12). Indeed, NOD CD8 ${ }^{+}$cDC1s express higher $\mathrm{CD} 40$ compared to $\mathrm{C} 57 \mathrm{Bl} / 6 \mathrm{CD} 8^{+} \mathrm{cDC} 1$. By contrast, targeting antigen to $\mathrm{DCIR} 2{ }^{+} \mathrm{CD} 11 \mathrm{~b}^{+} \mathrm{cDC} 2 \mathrm{~s}$ induce tolerogenic responses even in this chronic autoimmune environment and stimulation of $\mathrm{T}$ cells by DCIR2 ${ }^{+} \mathrm{cDC} 2 \mathrm{~s}$ can inhibit diabetes development (38).

Other studies have also suggested a regulatory role of $\mathrm{CD} 11 \mathrm{~b}^{+}$ cells in NOD mice, but it is not clear exactly what APC subsets are involved. Although tolerogenic $\mathrm{CD}_{11} \mathrm{~b}^{+} \mathrm{CD} 11 \mathrm{c}^{+}$cells abrogate diabetes when directed to the pancreas via increased CCL2 (30), other work shows that $\mathrm{CD}_{11 \mathrm{~b}^{+}}$DCs may be responsible 
TABLE 1 | Parameters of DC subsets relating to autoimmunity.

\begin{tabular}{|c|c|c|c|c|}
\hline $\begin{array}{l}\text { Dendritic cell } \\
\text { subsets }\end{array}$ & Plasmacytoid DCs & cDC1 & cDC2 & Monocyte-derived DCs \\
\hline Markers in mice & 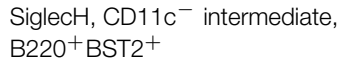 & $\begin{array}{l}\text { DEC205, XCR1, Clec9A, CD8, } \\
\text { or CD103 }\end{array}$ & CD11b, DCIR2 (33D1) & $\begin{array}{l}\text { CD11b CD11c MHCIl high, } \\
\text { DC-SIGN (CD209) DCIR2 negative }\end{array}$ \\
\hline Markers in human & $\begin{array}{l}\text { CLEC4C (BDCA2), CD123, } \\
\text { CD11c low/neg }\end{array}$ & $\begin{array}{l}\text { CD141 (BDCA3), XCR1, } \\
\text { Clec9A, }\end{array}$ & CD1c (BDCA1) & CD14, MR (CD206) \\
\hline Transcription factor & E2-2, Spi-B & Batf3, Irf8 & IRF4, Notch2 & Remains unclear \\
\hline Precursor & CDP & CDP & CDP & cMoP \\
\hline Main location & $\begin{array}{l}\text { Bone marrow and peripheral } \\
\text { lymphoid tissues }\end{array}$ & $\begin{array}{l}\text { Lymph nodes and peripheral } \\
\text { tissues }\end{array}$ & Spleen and peripheral tissues & $\begin{array}{l}\text { Rare in steady state, inflammation } \\
\text { recruits precursors from BM to } \\
\text { lymphoid and peripheral tissues }\end{array}$ \\
\hline $\begin{array}{l}\text { Role in autoimmune } \\
\text { pathogenesis }\end{array}$ & $\begin{array}{l}\text { Needed for early type I IFN that } \\
\text { elicits initiation of autoimmune } \\
\text { diabetes }\end{array}$ & $\begin{array}{l}\text { Efficient activation of } \mathrm{CD}^{+} \\
\mathrm{T} \text { cells through } \\
\text { cross-presentation }\end{array}$ & $\begin{array}{l}\text { Efficient proliferation of } \\
\text { pathogenic CD4 }{ }^{+} \mathrm{T} \text { cells }\end{array}$ & May expand effector T cells \\
\hline $\begin{array}{l}\text { Role in tolerance } \\
\text { induction }\end{array}$ & $\begin{array}{l}\text { Production of IDO, induction of } \\
\text { IL-10 and Trl }\end{array}$ & $\begin{array}{l}\text { Uptake of apoptotic cells and } \\
\text { induction of new Tregs }\end{array}$ & $\begin{array}{l}\text { Efficient proliferation of Tregs, } \\
\text { induction of Th2? }\end{array}$ & $\begin{array}{l}\text { In vitro-derived GM-CSF BM DCs } \\
\text { expand Tregs and inhibit diabetes }\end{array}$ \\
\hline $\begin{array}{l}\text { Alteration in } \\
\text { autoimmunity }\end{array}$ & $\begin{array}{l}\text { More type } 1 \text { IFN production. In } \\
\text { NOD, higher CD11c expression }\end{array}$ & $\begin{array}{l}\text { Inability to induce } \mathrm{CD}^{+} \mathrm{T} \text { cell } \\
\text { tolerance and Treg induction }\end{array}$ & $\begin{array}{l}\text { May be pathogenic and } \\
\text { tolerogenic, but not clear due to } \\
\text { lack of separation with } \\
\text { monocyte-derived CD11b+ cells }\end{array}$ & $\begin{array}{l}\text { In mice, more MHCllhi monocytes } \\
\text { due to inflammation. In T1D } \\
\text { patients, monocytes make more } \\
\text { pro-inflammatory cytokines }\end{array}$ \\
\hline Reference & $(4,8,9,23-25)$ & $(12,26-28)$ & $(29,30)$ & $(31-33)$ \\
\hline
\end{tabular}

for aberrant stimulation of beta-cell specific $\mathrm{CD} 4^{+} \mathrm{T}$ cells in NOD mice (23). Cells that are $\mathrm{CD}_{11} \mathrm{~b}^{+} \mathrm{CD} 11 \mathrm{c}^{+}$include $\mathrm{cDC} 2 \mathrm{~s}$ and monocyte-derived cells. Some of the monocyte-derived cells express high levels of MHC class II, especially in inflammatory settings (22). However, DCIR2 [and the corresponding antibody clone 33D1 (39)] is clearly specific for cDC2 cells, and use of this marker can separate monocyte-derived cells from cDC2s.

In addition to effects on the pathogenic T cells, $\mathrm{cDCs}$ can induce and expand autoantigen-specific Tregs that can block or reverse autoimmune pathology (40). Because DC interactions with Tregs can be enhanced by expression of costimulators, such as CD86 $(41,42)$, activation or maturation of DCs can sometimes have paradoxical effects on autoimmunity and the optimal DC state for tolerance maintenance may be semi-mature. DC subsets have different effects on Tregs. cDC1 DEC- $205^{+}$DCs can induce FoxP3 perhaps via TGF- $\beta$ expression, producing a regulatory compartment of autoreactive T cells (28). cDC2 CD11b ${ }^{+}$DCs do not express TGF- $\beta$ or efficiently induce Treg differentiation, but they expand existing populations of Tregs and can thus contribute to Treg-mediated suppression of autoimmunity $(28,43)$. However, factors other than TGF- $\beta$ likely have a role in Treg induction by these DC subsets, as TGF- $\beta$ may only have a minor role in conversion of Foxp $3^{-}$Treg precursors into Tregs (44). A recent study has shown the importance of migratory DCs in driving Treg responses (35). As these migratory DCs, which can express DEC-205, traffic from distal tissue sites containing antigens potentially relevant for autoimmune responses, defects in the ability of migratory DCs to induce or expand Tregs may inhibit self-tolerance and increase autoimmunity.

Like T1D, MS, and the associated mouse model, experimental autoimmune encephalomyelitis (EAE) are associated with aberrant $\mathrm{T}$ cell activation. Although DCs are not necessary for induction of EAE, several studies have demonstrated that DCs can permit immune invasion into the central nervous system (CNS) $(45,46)$. Both $\mathrm{CD}^{+}$and CD11b ${ }^{+}$DCs are found in the CNS during EAE, and can play a role in activating pathogenic T cells (47). Ablation of DCs in EAE models do not alter disease incidence but exhibit amelioration of disease severity, indicating that DCs play a role in priming pathogenic $\mathrm{T}$ cells or generating the inflammatory milieu (48). CD $11 b^{+}$DCs are located at the blood-brain barrier, and have been surmised to drive Th17 development that promotes EAE. Indeed, DCs are probably a major producer of inflammatory cytokines in the CNS during EAE induction and the acquisition of neuroantigens by DCs, as opposed to resident microglia, coincides with EAE symptom onset $(49,50)$.

Experimental autoimmune encephalomyelitis, and other induced autoimmune models, require immunization to break self-tolerance and initiate disease pathogenesis, and are models primarily for the effector phase of diseases such as MS and rheumatoid arthritis (51). But, immunization with a strong innate signal such as CFA may not be a good context to measure the state of innate immune and antigen-presenting function in a more chronic, but less dramatic, inflammatory environment such as that found during natural autoimmune pathogenesis. Therefore, in models such as EAE one can either intervene prior to immunization, when the mouse has no inflammation, or after immunization, when the inflammatory state may be distinct from the chronic inflammation that is found in tissue-specific autoimmune diseases. For example, several studies have shown that targeting self-antigen to DEC- $205^{+}$DCs to mice prior to inducing EAE can block disease, but the DCs are presenting antigen in a non-inflammatory context $(35,52,53)$. Targeting antigen to DEC-205 ${ }^{+} \mathrm{cDC} 1 \mathrm{~s}$ in NOD mice after initiation of autoimmunity induces an effector response, and $\mathrm{cDC} 1 \mathrm{~s}$ express higher levels of CD40 in NOD mice even without addition of TLRL or other innate stimulus (12). It is probable that other 
innate and regulatory pathways are deregulated in the context of chronic autoimmunity; therefore, it is important that tests of antigen-specific tolerance induction are performed in models such as the NOD mouse that may better reflect the immune state of autoimmune patients.

An unusual $\mathrm{cDC}$ population termed as merocytic DCs has been identified that are CD11 ${ }^{+}$MHCIIhi, but negative for both CD8 and CD11b (54). Interestingly, this population can acquire antigen from apoptotic fragments and is more numerous in NOD mice, a trait that maps to the insulin-dependent diabetes (Idd)13 genetic susceptibility locus (55). Transfer of purified merocytic DCs pulsed with beta cell antigen was shown to accelerate diabetes in NOD mice (56). However, a specific positive marker has not been identified for this population, making it difficult to ensure it is a uniform population and to determine if these cells more closely resemble $\mathrm{cDC} 1$ or $\mathrm{cDC} 2$.

\section{Plasmacytoid Dendritic Cells}

Plasmacytoid DCs are significant contributors of type 1 IFN after stimulation via TLR7 or TLR9 and as such can facilitate autoimmunity as is clearly the case with $\operatorname{SLE}(8,57)$. However, they can also play a significant role in regulation of immune responses by secreting IDO, inducing Tregs or inhibiting pathogenic responses $(23,24,58,59)$. Although evidence suggests that IFN- $\alpha$ from pDCs in the pancreas of NOD mice early (2-4 weeks of age) is important for initiation of autoimmune diabetes, other groups show that pDCs are only present in the islets later in the disease and play a protective role via $\operatorname{IDO}(4,9,23,25)$. A recent human study shows increased IFN- $\alpha$ from peripheral blood pDCs in patients with type 1 diabetes (60). It is possible that pDCs may be playing both a pathogenic and a regulatory role in T1D, depending on disease stage and microenvironment, but this needs further study. pDCs can also be relevant in some contexts for antigen presentation. For example, depleting pDCs exacerbates EAE and MHCII expression is needed on pDCs to inhibit $\operatorname{EAE}(58,59)$. Targeting of autoantigen to pDCs with antibodies against SiglecH (a lectin expressed specifically on pDCs) reduced CNS autoimmunity (61). Interestingly, although targeting antigen to $\mathrm{pDCs}$ via SiglecH-induced $\mathrm{T}$ cell regulation, antigen targeted to pDCs via BST2 resulted in immunity (62). Two possible explanations for the divergent response are that (1) siglecH has an ITIM motif, and when antibody binds, $\mathrm{pDCs}$ produce less IFN and (2) although BST2 is specific to pDCs in non-inflamed environments, many other APCs can upregulate BST2 with inflammation (63).

\section{Monocyte-Derived Cells}

There are also several monocyte-derived cell populations that appear to have therapeutic potential and the ability to drive $\mathrm{T}$ cell tolerance via cell-intrinsic mechanisms or Treg induction. As discussed above, some studies identifying roles for CD11b ${ }^{+}$ cells may actually be studying a monocyte-related population, not cDCs. Bone marrow DCs generated in vitro with GMCSF are monocyte derived. GM-CSF BMDCs efficiently stimulate proliferation of self-specific Tregs that can effectively block and reverse diabetes pathogenesis $(31,64)$. Both GM-CSF/IL-4derived DCs and IL-10-derived DCs are tolerogenic monocytederived populations that can alter Treg populations and inhibit autoreactivity $(65,66)$. These tolerogenic DCs are being actively studied for possible therapies in human autoimmunity and for blocking medical complications such as graft-versus-host disease $(67,68)$. On the other hand, T1D patients have activated monocytes in the peripheral blood that make elevated levels of proinflammatory cytokines (32). Therefore, monocyte-derived DCs, like other DC subsets, also can provide both tolerogenic and immune activating signals that alter autoimmune pathogenesis (Figure 1).

\section{The Role of DC Development in Autoimmunity}

Induction and maintenance of $\mathrm{T}$ cell tolerance can be affected by alterations in DC development, which occur via hematopoetic bone marrow precursors that become more specialized toward the DC lineage, starting with committed myeloid precursors (c-kit ${ }^{+} \mathrm{CX} 3 \mathrm{CR} 1^{+} \mathrm{Lin}^{-}$), monocyte and DC precursors (c-kit ${ }^{+} \mathrm{CX} 3 \mathrm{CR} 1^{-} \mathrm{Lin}^{-}$), and committed DC precursors (c-kit ${ }^{\text {lo }} \mathrm{CX} 3 \mathrm{CR} 1^{+} \mathrm{CD}_{115^{+}} \mathrm{Lin}^{-}$) (69). pDCs are an independent lineage that branch off from the cDCs at the CDP stage. TNF- $\alpha$ /iNOS-producing DCs and Gr- $1^{+}$inflammatory DCs differentiate from monocytes during inflammation via GM-CSF, but are rare in steady-state mice $(14,70,71)$.

Flt3L is known to be essential for the development of DCs. pDCs and cDCs can be generated in vitro by culturing bone marrow cells (that include DC precursors) with Flt3L. Exogenous Flt3L boosts mouse and human DC numbers in vivo, including both $\mathrm{cDC} 1$ and $\mathrm{cDC} 2(72,73)$. Increased Flt3L expression results in an increase in Tregs that correlates with the total number of $\mathrm{CD}_{11 \mathrm{c}^{+}}$cells (5). Studies using different timing of Flt3L treatment demonstrated that DCs can either ameliorate type 1 diabetes when given early in life or increase disease severity if Flt3L is given at later time-points when pre-existing autoimmune $\mathrm{T}$ cells are present (74). This underscores the dual nature of DC actions on $\mathrm{T}$ cells in autoimmune disease.

Dendritic cells in NOD mice exhibit alteration from development of DC subsets. CDC1 is underrepresented in NOD mice (75). Indeed, studies using Flt3L treatment of NOD mice increased $\mathrm{CD}^{+} \mathrm{DC}$ numbers and ameliorated disease, indicating that DCs are important for inhibiting diabetes progression (76). However, more recent studies have determined that Batf3dependent DCs are necessary for induction of diabetes (77). Batf3 is a transcription factor that regulates $\mathrm{CDC1}$ differentiation (78). These results highlight the dual roles that DCs play in autoimmune responses (77). NOD mice also express lower levels of IL-2 at steady-state than non-autoimmune-prone mice (79). IL-2 is a diabetes-associated gene located within the Idd3 loci. Although research has focused on the role of IL-2 on T cells and specifically Treg numbers in diabetes, IL-2 also affects DC development. The lower levels of IL-2 present in NOD mice lead to increased numbers of DCs and could play a role in aberrant $\mathrm{T}$ cell activation. The increased spleen $\mathrm{pDC}$ numbers observed in NOD but not Idd3/5 mice, inversely correlate with respective IL-2 levels (80). Therefore, alterations in DC development can alter pathogenesis of diabetes and other autoimmune diseases. 


\section{Genetic Susceptibility Genes can Alter Autoimmune Pathogenesis via Effects on Antigen Presentation and Innate Immunity}

The genetic region with the highest risk association in most autoimmune diseases is MHCII (81), which links autoimmunity to antigen presentation. Exactly how particular alleles of MHCII confer susceptibility or resistance is still not clear after decades of extensive study, but the most widely held theory is that particular alleles direct repertoire selection in the thymus, and may affect the specificity of peripheral tolerance as well. Other genes associated with APCs have also been linked to various autoimmune diseases. For example, as stated previously in the section on pDCs, genes related to type 1 IFN are implicated in a number of autoimmune diseases (82). In models of diseases such as SLE, several studies have indicated that a loss of negative regulators of inflammation (such as A20, Shp1, and Blimp1) specifically in DCs lead to autoimmune phenotypes (83-86).

Some susceptibility genes, such as IL-2, protein-tyrosine phosphatase, non-receptor type 22 (PTPN22), and B lymphocyteinduced maturation protein 1 (BLIMP1), studied primarily for functional roles in lymphocytes also affect DC phenotype (8387). BLIMP1 is a transcriptional repressor that modulates the MHCII loci, but can be ubiquitinated by the ubiquitin ligase Hrd1 to increase MHCII expression in DCs, and loss of Hrd1 protected against EAE (88). PTPN22 is a tyrosine phosphatase that is directly involved in TLR-mediated signaling and can profoundly affect type 1 IFN production in innate immune cells (89). In type 1 diabetes, many of the identified susceptibility loci affect APCs. Genes in the Idd4 locus can alter both IL-12 and IFN responses that affect antigen presentation and the type of $\mathrm{T}$ cell responses that ensue (90). Bone marrow chimera studies have shown that $I d d 3 / 5$ and $I d d 9$ can affect diabetes pathogenesis in $\mathrm{T}$ cell-independent, DC-dependent manner, although the particular DC subsets involved have not been elucidated $(91,92)$. Idd3 encodes IL-21 in addition to IL-2, and polymorphic variants of IL21 and its receptor have been implicated in genetic susceptibility to T1D (93). IL-21R-deficient DCs fail to acquire expression of CCR7 to shuttle between the pancreas and draining lymph nodes or efficiently express MHCII to induce autoreactive $\mathrm{T}$ cell pathogenesis (94). Data utilizing NOD mice congenic for the diabetes-resistant alleles at the Idd 3 and $I d d 5$ loci demonstrated that expression of these alleles is important in DCs for $\mathrm{CD}_{4}^{+} \mathrm{T}$ and $\mathrm{CD}^{+} \mathrm{T}$ cell tolerance. Therefore, the disease-altering effects of these two loci come from both lymphoid and non-lymphoid cells, and this may be a common feature of genetic risk.

\section{The Level of DC Maturation and Response to Environmental Stimuli can Alter Autoimmune Pathogenesis}

Dendritic cells respond to numerous maturation signals during host responses. An array of innate receptors, including TLRs NOD-like receptors, RIG-I-like receptors, and AIM2-like receptors, as well as receptors for inflammatory cytokines, are expressed by DCs and act as environmental sensors. These receptors bind ligands from the local microenvironment and induce maturation of DCs, acting as a switch to induce effective adaptive immune responses. In addition to pathogen-associated molecular patterns, these innate receptors can bind endogenous ligands or dangerassociated molecular patterns, which can alter DC phenotype and function. Host-generated chronic inflammation during autoimmune pathogenesis is one source of this non-pathogen-associated innate immune signal (3). Because of these activating signals, DCs in autoimmune individuals have an altered ability to induce tolerance [reviewed in Ref. (95)]. DCs play a major role in the homeostasis of regulatory $\mathrm{T}$ cells (Tregs) and can thus also indirectly influence effector $\mathrm{T}$ cell activation and tolerance via these cells. These interactions change at different stages of disease (Figure 1). Therefore, DCs can contribute both to the pathogenesis and regulation of autoimmunity.

The cytokine milieu in an autoimmune-prone individual or animal can have important effects on DC phenotypes. Alterations in DCs in NOD mice have been linked to diabetes progression, and a type 1 interferon signature has been noted prior to $\mathrm{T}$ cell activation within the pancreas $(96,97)$. GM-CSF BMDCs from NOD mice express increased NF- $\mathrm{KB}$ and higher levels of the Th1-inducing cytokine IL-12 and adenosine deaminase, although it is not yet clear if cDCs display similar responses (33, 98, 99). Migratory DC populations express lower levels of the immunomodulatory cytokine IL-10 in NOD mice as compared to non-autoimmune-prone strains (13). TNF- $\alpha$, which can be produced in response to environmental stimuli that signal via pattern recognition receptors, may be one major modulator of DC function in autoimmune disease. Mice treated neonatally with TNF- $\alpha$ exhibited more rapid diabetes progression that correlated with increased expression of costimulatory proteins on $\mathrm{CD}_{1} 1 \mathrm{~b}^{+}$ DC subsets, while decreasing the number of $\mathrm{CD}^{+} \mathrm{DC}$ in the pancreatic lymph nodes (100).

Pro-inflammatory DC function has been observed in MS, and interferon- $\beta$ is used to treat the disease. Although the precise mechanism is not clear, IFN- $\beta$ may act on DCs by inhibiting trafficking or reducing $\mathrm{T}$ cell activation, possibly via $\mathrm{DC}$ apoptosis $(101,102)$. By contrast, type 1 interferons have been prominently implicated in SLE pathogenesis, linking the disease to pDCs. Immune cells from SLE patients display a type 1 IFN signature, and their $\mathrm{pDCs}$ have a greater capacity for stimulating pathogenic $\mathrm{T}$ cells than pDCs from control patients (103). In new-onset T1D patients, an IL-1 signature has been measured, yet mouse models of T1D indicate an early role for type 1 IFN and T1D patients may have increases in IFN- $\alpha$-producing pDCs $(60,104)$. Therefore, the nature of the inciting innate responses is not the same for all autoimmune diseases, and more work needs to be done to define the innate landscape in both human autoimmunity and the corresponding mouse models.

In addition to cytokines, surface costimulatory markers are altered in DCs from NOD mice. Our work has demonstrated that $\mathrm{CD}^{+}$DCs from NOD mice express increased levels of CD40 and that this increase alters their stimulatory capacity for selfspecific $\mathrm{CD} 4^{+} \mathrm{T}$ cells (12). In the context of autoimmune gastritis, migratory DCs from the stomach also express a semi-activated phenotype with small increases in CD40, CD86, and MHCII. However, unlike the shift to effector $\mathrm{T}$ cell responses in NOD mice, 
these semi-activated DCs are refractory to TLR stimulation and maintain their ability to induce tolerant $\mathrm{CD} 4^{+} \mathrm{T}$ cells even in the presence of DC maturation factors (105). NOD mice that lack the interaction between CD28 on T cells and CD80/CD86 on APCs display accelerated disease and lack Tregs, showing that these positive costimulators associated with inflammation are also needed to maintain tolerance (15). DC responses to chronic inflammation may be regulated by a number of mechanisms. Therefore, changes in DC phenotype directly affect pathogenic and tolerogenic T cell responses in autoimmunity.

Another source of innate signals is the microbiome, and alterations in the composition of gut flora have been linked to human autoimmune disease $(106,107)$. For example, in T1D, studies of microbial composition in at risk individuals found that seroconverted subjects had lower diversity prior to disease onset (108), and lower levels of bacteria that produce the regulatory metabolite butyrate compared to controls that did not develop autoantibodies (109). In mouse models, where it is possible to go beyond correlation and dissect mechanism, manipulations of microbial content can alter autoimmune pathogenesis. In a model of arthritis, the presence of segmented filamentous bacteria in the gut induces systemic immune alterations, increased Th17 responses, and was necessary for full arthritis development; these bacteria alter diabetes pathogenesis in NOD mice as well $(110,111)$. Commensal flora is important triggers in a relapsing-remitting EAE model, advancing both pathogenic $\mathrm{T}$ and $\mathrm{B}$ cell responses (112). In NOD mice, the effects of microbiota on disease progression are complex. Mice lacking Myd88 (that cannot respond to most TLR signals) do not get diabetes, but NOD.Myd $88^{-1-}$ mice in germ-free conditions do develop diabetes that can be blocked by transfer of defined microbial communities (10). Gender and hormonal differences also alter gut microbial composition and alter diabetes risk $(113,114)$. Indeed, the mechanisms by which microbial communities influence specific DC populations are just beginning to be defined (115), but these changes could in turn affect autoimmune pathogenesis.

Paradoxically, innate immune stimulators such as TLR agonists can sometimes inhibit autoimmunity. In NOD mice, weekly injections of many different TLR ligands, including poly(I:C) (TLR3 agonist), LPS (TLR4 agonist), or P40 protein from Klebsiella (TLR2 agonist), can block diabetes development if started at weaning (116). Poly(I:C) can block disease if treatment is started as late as 10 weeks of age, soon before the mice begin to develop diabetes. The effect of eliminating TLR signaling varies depending on the receptor. TLR9 expression is needed for development of diabetes and EAE in mouse models $(117,118)$. Conversely, TLR4 deficiency accelerates diabetes development in NOD mice (119). Therefore, the contribution of TLR signals to autoimmunity is complex, and can either inhibit or exacerbate disease.

\section{Effects of DC Maturation Thresholds on Development of Autoimmunity}

The balance between tolerance and chronic inflammation associated with autoimmune disease can shift with relatively minor changes in DC phenotype. And although DCs can be sufficient for inducing autoimmune disease in several models, often other
APC populations will drive disease in the absence of DCs. Costimulatory proteins on T cells and DCs act on multiple levels to affect autoimmune phenotypes, often altering the effector $\mathrm{T}$ cell to regulatory $\mathrm{T}$ cell ratio. Because some of the same costimulatory signals are needed for stimulation of effector $\mathrm{T}$ cells and Treg, a small change in level can alter the balance between these two cell types. CD28 and CD40 have disparate effects on inducing these $\mathrm{T}$ cell fates in NOD mice, as a loss of CD28 can restore diabetes in CD40L-deficient mice and alters the number of Tregs in those mice (120).

Changes in DC phenotype due to an inflamed system may be at a lower level than those observed due to treatment with exogenous stimulants or during acute infection. However, these changes can have dramatic effects on disease progression. For example, the less than twofold increase in CD40 on CD8 ${ }^{+}$DCs in NOD mice likely helps cause a switch from tolerance to effector responses in autoreactive T cells (12). CD40 expression levels affecting $\mathrm{T}$ cell fate is also observed in $\mathrm{T}$ cell responses to CD40 heterozygous mice. In a Leishmania infection model, CD40 ${ }^{+1-}$ DCs-induced regulatory $\mathrm{T}$ cells while CD40 ${ }^{+/+}$DCs-induced effector T cells, while exacerbating or dampening disease, respectively (121). Indeed, these effects can be observed during both Treg and Teff stimulation. Lower levels of CD40 on DCs were associated with higher numbers of Tregs and inhibition of diabetes in an infection-driven model of type 1 diabetes (122). Expression of higher CD40 levels on APCs induced a greater proportion of effector T cells (123).

These subtle differences in DC phenotype leading to large differences in $\mathrm{T}$ cell outcomes present the possibility of a threshold effect. As shown with the Leishmania model, altering CD40 levels without completely losing those signals or overexpressing the protein can cause a profound change in $\mathrm{T}$ cell responses and alter the systemic immune response. DCs play an important role in the maintenance of immune homeostasis, and disrupting their phenotype by a small amount could lead to severe downstream alterations in effector responses. Thus, whether by genetic means or by inflammation from secondary sources, altered DC costimulation may push $\mathrm{T}$ cell and subsequent $\mathrm{B}$ cell responses to be aberrantly reactive to self-proteins, starting off autoimmune pathogenesis.

\section{Alterations in DCs due to Chronic Inflammation: Comparison to Infection}

The inflammation that occurs during autoimmune pathogenesis may have parallels with the $T$ cell responses during chronic infection because long-lasting effector $\mathrm{T}$ cell responses can alter the inflammatory state of a host, both via pro- and anti-inflammatory mechanisms. The generation of antimicrobial $\mathrm{T}$ cells can produce responses that have inflammatory effects on host tissues, as well as regulatory mechanisms to minimize host tissue damage (124). Autoimmune diseases that have environmental etiologies may have infectious triggers, and secondary autoimmunity can be triggered via molecular mimicry or pathogen-induced inflammatory environment (125). Indeed, altering the inflammatory status of DCs alters T cell responses and autoimmune pathology [reviewed in Ref. (126)]. Increased inflammation observed 
during autoimmune pathogenesis has several similarities to the host response to infection, and emerging studies have demonstrated that DC subsets play distinct roles during infection as well as during autoimmunity. We hypothesize that cellular responses including DC-driven immunity associated with a type 1 IFN signature may be similar regardless if the context is autoimmunity or chronic viral infections. The counterregulatory pathways associated with chronic stimulation could lead to an impaired ability of DCs to maintain Treg homeostasis.

It has been shown in the context of infection that different DC subsets can produce $\mathrm{T}$ effector responses through distinct mechanisms. For example, $\mathrm{CD} 8^{+} \mathrm{DCs}$ induce Th1 responses via CD70, while CD11b ${ }^{+}$DCs induce Th1 responses in an IL-12dependent fashion (127). DC subsets can also induce disparate $\mathrm{T}$ cell responses during the same infection. In the lung during influenza infection, $\mathrm{CD}_{103}{ }^{+} \mathrm{DCs}$ induce effector $\mathrm{CD} 8^{+} \mathrm{T}$ cells via $\mathrm{CD} 24$, while $\mathrm{CD} 11 \mathrm{~b}^{+}$DCs have reduced levels of $\mathrm{CD} 24$ and induce memory CD8 ${ }^{+} \mathrm{T}$ cells (128). Targeting of antigen to DC subsets can strong immunity in a variety of inflammatory settings. Targeting to cDC1 has long-lasting effects on T cell help for B cells, increasing responses against microbial pathogens, although this effect has not been tested for autoantigenic determinants (129). Targeting of antigen to DCs has also been harnessed in mouse models in anti-cancer therapeutics that demonstrate the power of DCs to turn T cell responses against self-tissues to good use. Protective immune responses against both HER2/neu breast cancer ( $\mathrm{CDC} 1)$ and melanoma ( $\mathrm{CDC} 1$ and $\mathrm{cDC} 2$ ) have been induced by DC-targeted therapies $(130,131)$.

The type 1 interferons that generate a genetic signature often observed during autoimmune pathogenesis prior to overt disease are produced via distinct mechanisms in DC subsets. In response to measles virus, $\mathrm{pDCs}$ produce type 1 interferons through TLR7 or TLR9-MyD88-dependent pathway, while $\mathrm{CD}^{+}$DCs can produce type 1 interferons through Rig-I and MDA5 or TLR3-TRIF (132). DCs responding to respiratory syncytial virus also produce distinct $\mathrm{T}$ cell profiles. While infected human $\mathrm{BDCA}-1^{+} \mathrm{DCs}$ induce a Th1 response in T cells, BDCA- $3^{+}$DCs induce Th2 and Treg responses (133). These distinct responses to pathogens based on the DC subset responding appear similar to what we have observed in NOD mice, wherein $\mathrm{CDC1}$ produce effector responses while $\mathrm{cDC} 2$ are tolerogenic. Therefore, the inflammatory environment that is present during autoimmunity or infection may influence the phenotype of different DC subsets in distinct manners, and thus produce surprisingly different $\mathrm{T}$ cell responses.

\section{Blocking DC Alterations to Maintain T Cell Tolerance}

Several costimulatory pathways in DCs have been manipulated to alter disease by affecting activation and proliferation of both effector T cells and regulatory T cells [reviewed in Ref. (134)]. The NOD mouse has been utilized to study several different mechanisms of blocking costimulatory pathways, both genetically and pharmacologically $(120,135,136)$. Some of these therapies have been translated for use in type 1 diabetes patients: treatment with CTLA-4-Ig was successful in delaying disease, but was not successful in reversing disease course, with continued loss of $\mathrm{C}$-peptide, a byproduct of insulin processing that is a marker of endogenous insulin production $(137,138)$. In mice, the TNFfamily receptors OX40 and OX40L can be manipulated to prevent diabetes, probably via changes in regulatory T cells $(139,140)$. Although promising results with blockade of CD28 and CD40 in mouse models of SLE ameliorate disease and reduce the severity of disease indicators such as class-switched B cells and autoreactiveIgG, little efficacy was observed when targeting CD28, CD40, and ICOS in SLE patients (141-143). Blocking inflammatory cytokines that can alter DC phenotype has also been examined. One case report and one small study suggest that TNF- $\alpha$ blockade in patients with recent onset T1D may preserve beta cell function $(144,145)$. The timing of immunotherapies is often critical for successfully treating autoimmune disease. Several therapies were successful in reversing diabetes in NOD mice only when used during specific time intervals, whether those were several weeks prior to or post disease diagnosis (146).

\section{Implications for Designing New Therapies to Treat Autoimmunity}

Given the relative lack of success at treating autoimmune disease with therapies targeting a single disease mechanism, it seems that combination therapies including both an antigen-specific component and an alteration of the inflammatory environment will likely be necessary to ameliorate disease. The central role of DCs in connecting innate and adaptive immune responses makes them an attractive target for at least part of that therapeutic regimen. Therefore, incorporation of the knowledge of the developmental and inflammatory signals that affect DC phenotype is critical in producing desired therapeutic outcomes. Understanding the differences in responses of specific DC subsets to these internal and external influences in the context of specific autoimmune diseases could lead to a significant increase in the effectiveness of therapeutics. Therapies designed to target antigen to specific DC subsets able to induce tolerance in that specific context may be more successful than non-specific delivery of antigen to many different APCs with varying activation states and phenotypes. Likewise, better characterization of the status of costimulatory molecules on the surface of DC subsets will help to determine which DC subsets will optimally induce tolerance. Knowing the leverage points at which DCs will produce effector responses or suppress $\mathrm{T}$ cell responses (especially for known or suspected initiating antigens) is an important characteristic of which therapeutic strategies can take advantage in ameliorating autoimmune disease.

\section{Acknowledgments}

We would like to thank Dr. Chie Hotta-Iwamura for suggestions and editing this review. This work was supported by the Intramural Research Program of the National Institute of Diabetes and Digestive and Kidney Diseases. 


\section{References}

1. Calderon B, Carrero JA, Miller MJ, Unanue ER. Cellular and molecular events in the localization of diabetogenic $\mathrm{T}$ cells to islets of Langerhans. Proc Natl Acad Sci U S A (2011) 108:1561-6. doi:10.1073/pnas.1018973108

2. Billiard F, Lobry C, Darrasse-Jeze G, Waite J, Liu X, Mouquet H, et al. Dll4-Notch signaling in Flt3-independent dendritic cell development and autoimmunity in mice. J Exp Med (2012) 209:1011-28. doi:10.1084/jem. 20111615

3. Santin I, Eizirik DL. Candidate genes for type 1 diabetes modulate pancreatic islet inflammation and beta-cell apoptosis. Diabetes Obes Metab (2013) 15(Suppl 3):71-81. doi:10.1111/dom.12162

4. Diana J, Simoni Y, Furio L, Beaudoin L, Agerberth B, Barrat F, et al. Crosstalk between neutrophils, B-1a cells and plasmacytoid dendritic cells initiates autoimmune diabetes. Nat Med (2013) 19:65-73. doi:10.1038/nm.3042

5. Darrasse-Jeze G, Deroubaix S, Mouquet H, Victora GD, Eisenreich T, Yao $\mathrm{KH}$, et al. Feedback control of regulatory $\mathrm{T}$ cell homeostasis by dendritic cells in vivo. J Exp Med (2009) 206:1853-62. doi:10.1084/jem.20090746

6. Ohnmacht C, Pullner A, King SB, Drexler I, Meier S, Brocker T, et al. Constitutive ablation of dendritic cells breaks self-tolerance of CD4 T cells and results in spontaneous fatal autoimmunity. J Exp Med (2009) 206:549-59. doi:10.1084/jem.20082394

7. Teichmann LL, Ols ML, Kashgarian M, Reizis B, Kaplan DH, Shlomchik MJ. Dendritic cells in lupus are not required for activation of T and B cells but promote their expansion, resulting in tissue damage. Immunity (2010) 33:967-78. doi:10.1016/j.immuni.2010.11.025

8. Rowland SL, Riggs JM, Gilfillan S, Bugatti M, Vermi W, Kolbeck R, et al. Early, transient depletion of plasmacytoid dendritic cells ameliorates autoimmunity in a lupus model. J Exp Med (2014) 211:1977-91. doi:10.1084/jem.20132620

9. Li Q, Xu B, Michie SA, Rubins KH, Schreriber RD, McDevitt HO. Interferonalpha initiates type 1 diabetes in nonobese diabetic mice. Proc Natl Acad Sci U S A (2008) 105:12439-44. doi:10.1073/pnas.0806439105

10. Wen L, Ley RE, Volchkov PY, Stranges PB, Avanesyan L, Stonebraker AC, et al. Innate immunity and intestinal microbiota in the development of Type 1 diabetes. Nature (2008) 455:1109-13. doi:10.1038/nature07336

11. Diana J, Brezar V, Beaudoin L, Dalod M, Mellor A, Tafuri A, et al. Viral infection prevents diabetes by inducing regulatory $\mathrm{T}$ cells through NKT cellplasmacytoid dendritic cell interplay. J Exp Med (2011) 208:729-45. doi:10. 1084/jem.20101692

12. Price JD, Beauchamp NM, Rahir G, Zhao Y, Rieger CC, Lau-Kilby AW, et al. CD8+ dendritic cell-mediated tolerance of autoreactive CD4+ T cells is deficient in NOD mice and can be corrected by blocking CD40L. J Leukoc Biol (2014) 95:325-36. doi:10.1189/jlb.0113013

13. Welzen-Coppens JM, van Helden-Meeuwsen CG, Leenen PJ, Drexhage HA, Versnel MA. Reduced numbers of dendritic cells with a tolerogenic phenotype in the prediabetic pancreas of NOD mice. J Leukoc Biol (2012) 92:1207-13. doi: $10.1189 / \mathrm{jlb} .0312168$

14. Serbina NV, Salazar-Mather TP, Biron CA, Kuziel WA, Pamer EG. TNF/iNOSproducing dendritic cells mediate innate immune defense against bacterial infection. Immunity (2003) 19:59-70. doi:10.1016/S1074-7613(03)00171-7

15. Salomon B, Lenschow DJ, Rhee L, Ashourian N, Singh B, Sharpe A, et al. B7/CD28 costimulation is essential for the homeostasis of the CD4+CD25+ immunoregulatory T cells that control autoimmune diabetes. Immunity (2000) 12:431-40. doi:10.1016/S1074-7613(00)80195-8

16. Guilliams M, Ginhoux F, Jakubzick C, Naik SH, Onai N, Schraml BU, et al. Dendritic cells, monocytes and macrophages: a unified nomenclature based on ontogeny. Nat Rev Immunol (2014) 14:571-8. doi:10.1038/nri3712

17. Crozat K, Guiton R, Contreras V, Feuillet V, Dutertre CA, Ventre E, et al. The XC chemokine receptor 1 is a conserved selective marker of mammalian cells homologous to mouse CD8alpha+ dendritic cells. J Exp Med (2010) 207:1283-92. doi:10.1084/jem.20100223

18. Poulin LF, Salio M, Griessinger E, Anjos-Afonso F, Craciun L, Chen JL, et al. Characterization of human DNGR-1+ BDCA3+ leukocytes as putative equivalents of mouse CD8alpha+ dendritic cells. J Exp Med (2010) 207:1261-71. doi:10.1084/jem.20092618

19. Blasius AL, Cella M, Maldonado J, Takai T, Colonna M. Siglec-H is an IPCspecific receptor that modulates type I IFN secretion through DAP12. Blood (2006) 107:2474-6. doi:10.1182/blood-2005-09-3746

20. Dzionek A, Sohma Y, Nagafune J, Cella M, Colonna M, Facchetti F, et al. BDCA-2, a novel plasmacytoid dendritic cell-specific type II C-type lectin, mediates antigen capture and is a potent inhibitor of interferon alpha/beta induction. J Exp Med (2001) 194:1823-34. doi:10.1084/jem.194.12.1823

21. Jakubzick C, Gautier EL, Gibbings SL, Sojka DK, Schlitzer A, Johnson TE, et al. Minimal differentiation of classical monocytes as they survey steady-state tissues and transport antigen to lymph nodes. Immunity (2013) 39:599-610. doi:10.1016/j.immuni.2013.08.007

22. Cheong C, Matos I, Choi JH, Dandamudi DB, Shrestha E, Longhi MP, et al Microbial stimulation fully differentiates monocytes to DC-SIGN/CD209(+) dendritic cells for immune $T$ cell areas. Cell (2010) 143:416-29. doi:10.1016/j. cell.2010.09.039

23. Saxena V, Ondr JK, Magnusen AF, Munn DH, Katz JD. The countervailing actions of myeloid and plasmacytoid dendritic cells control autoimmune diabetes in the nonobese diabetic mouse. J Immunol (2007) 179:5041-53. doi:10.4049/jimmunol.179.8.5041

24. Baban B, Chandler PR, Sharma MD, Pihkala J, Koni PA, Munn DH, et al. IDO activates regulatory $\mathrm{T}$ cells and blocks their conversion into Th17-like $\mathrm{T}$ cells. J Immunol (2009) 183:2475-83. doi:10.4049/jimmunol.0900986

25. Welzen-Coppens JM, van Helden-Meeuwsen CG, Leenen PJ, Drexhage HA, Versnel MA. The kinetics of plasmacytoid dendritic cell accumulation in the pancreas of the NOD mouse during the early phases of insulitis. PLoS One (2013) 8:e55071. doi:10.1371/journal.pone.0055071

26. den Haan JM, Lehar SM, Bevan MJ. CD8(+) but not CD8(-) dendritic cells cross-prime cytotoxic T cells in vivo. J Exp Med (2000) 192:1685-96. doi:10. 1084/jem.192.12.1685

27. Mukhopadhaya A, Hanafusa T, Jarchum I, Chen YG, Iwai Y, Serreze DV, et al. Selective delivery of beta cell antigen to dendritic cells in vivo leads to deletion and tolerance of autoreactive CD8+ T cells in NOD mice. Proc Natl Acad Sci U S A (2008) 105:6374-9. doi:10.1073/pnas.0802644105

28. Yamazaki S, Dudziak D, Heidkamp GF, Fiorese C, Bonito AJ, Inaba K, et al. CD8+ CD205+ splenic dendritic cells are specialized to induce Foxp3+ regulatory T cells. J Immunol (2008) 181:6923-33. doi:10.4049/jimmunol.181.10. 6923

29. Dudziak D, Kamphorst AO, Heidkamp GF, Buchholz VR, Trumpfheller C, Yamazaki S, et al. Differential antigen processing by dendritic cell subsets in vivo. Science (2007) 315:107-11. doi:10.1126/science.1136080

30. Kriegel MA, Rathinam C, Flavell RA. Pancreatic islet expression of chemokine CCL2 suppresses autoimmune diabetes via tolerogenic CD11c+CD11b+ dendritic cells. Proc Natl Acad Sci U S A (2012) 109:3457-62. doi:10.1073/pnas. 1115308109

31. Tarbell KV, Yamazaki S, Olson K, Toy P, Steinman RM. CD25+ CD4+ T cells, expanded with dendritic cells presenting a single autoantigenic peptide, suppress autoimmune diabetes. J Exp Med (2004) 199:1467-77. doi:10.1084/ jem. 20040180

32. Bradshaw EM, Raddassi K, Elyaman W, Orban T, Gottlieb PA, Kent SC, et al. Monocytes from patients with type 1 diabetes spontaneously secrete proinflammatory cytokines inducing Th17 cells. J Immunol (2009) 183:4432-9. doi:10.4049/jimmunol.0900576

33. Marleau AM, Singh B. Myeloid dendritic cells in non-obese diabetic mice have elevated costimulatory and T helper-1-inducing abilities. J Autoimmun (2002) 19:23-35. doi:10.1006/jaut.2002.0597

34. Hawiger D, Inaba K, Dorsett Y, Guo M, Mahnke K, Rivera M, et al. Dendritic cells induce peripheral $\mathrm{T}$ cell unresponsiveness under steady state conditions in vivo. J Exp Med (2001) 194:769-79. doi:10.1084/jem.194.6.769

35. Idoyaga J, Fiorese C, Zbytnuik L, Lubkin A, Miller J, Malissen B, et al. Specialized role of migratory dendritic cells in peripheral tolerance induction. J Clin Invest (2013) 123:844-54. doi:10.1172/JCI65260

36. Bonifaz L, Bonnyay D, Mahnke K, Rivera M, Nussenzweig MC, Steinman RM. Efficient targeting of protein antigen to the dendritic cell receptor DEC-205 in the steady state leads to antigen presentation on major histocompatibility complex class I products and peripheral CD8+ T cell tolerance. J Exp Med (2002) 196:1627-38. doi:10.1084/jem.20021598

37. Finkelman FD, Lees A, Birnbaum R, Gause WC, Morris SC. Dendritic cells can present antigen in vivo in a tolerogenic or immunogenic fashion.J Immunol (1996) 157:1406-14.

38. Price JD, Hotta-Iwamura C, Zhao Y, Beauchamp NM, Tarbell KV. DCIR2 ${ }^{+}$ cDC2 DCs and Zbtb32 restore $\mathrm{CD}^{+} \mathrm{T}$ cell tolerance and inhibit diabetes. Diabetes (2015) (in press).

39. Nussenzweig MC, Steinman RM, Witmer MD, Gutchinov B. A monoclonal antibody specific for mouse dendritic cells. Proc Natl Acad Sci U S A (1982) 79:161-5. doi:10.1073/pnas.79.1.161 
40. Luo X, Tarbell KV, Yang H, Pothoven K, Bailey SL, Ding R, et al. Dendritic cells with TGF-betal differentiate naive $\mathrm{CD} 4+\mathrm{CD} 25-\mathrm{T}$ cells into islet-protective Foxp3+ regulatory T cells. Proc Natl Acad Sci U S A (2007) 104:2821-6. doi:10.1073/pnas.0611646104

41. Yamazaki S, Iyoda T, Tarbell K, Olson K, Velinzon K, Inaba K, et al. Direct expansion of functional CD25+ CD4+ regulatory T cells by antigenprocessing dendritic cells. J Exp Med (2003) 198:235-47. doi:10.1084/jem. 20030422

42. Zheng Y, Manzotti CN, Liu M, Burke F, Mead KI, Sansom DM. CD86 and CD80 differentially modulate the suppressive function of human regulatory T cells. J Immunol (2004) 172:2778-84. doi:10.4049/jimmunol.172.5.2778

43. Bhattacharya P, Gopisetty A, Ganesh BB, Sheng JR, Prabhakar BS. GM-CSFinduced, bone-marrow-derived dendritic cells can expand natural tregs and induce adaptive tregs by different mechanisms. J Leukoc Biol (2011) 89:235-49. doi:10.1189/jlb.0310154

44. Schallenberg S, Tsai PY, Riewaldt J, Kretschmer K. Identification of an immediate Foxp3(-) precursor to Foxp3(+) regulatory T cells in peripheral lymphoid organs of nonmanipulated mice. J Exp Med (2010) 207:1393-407. doi:10.1084/ jem. 20100045

45. Greter M, Heppner FL, Lemos MP, Odermatt BM, Goebels N, Laufer T, et al. Dendritic cells permit immune invasion of the CNS in an animal model of multiple sclerosis. Nat Med (2005) 11:328-34. doi:10.1038/nm1197

46. McMahon EJ, Bailey SL, Castenada CV, Waldner H, Miller SD. Epitope spreading initiates in the CNS in two mouse models of multiple sclerosis. Nat Med (2005) 11:335-9. doi:10.1038/nm1202

47. Bailey SL, Schreiner B, McMahon EJ, Miller SD. CNS myeloid DCs presenting endogenous myelin peptides 'preferentially' polarize $\mathrm{CD} 4+\mathrm{T}(\mathrm{H})-17$ cells in relapsing EAE. Nat Immunol (2007) 8:172-80. doi:10.1038/ni1430

48. Isaksson M, Lundgren BA, Ahlgren KM, Kampe O, Lobell A. Conditional DC depletion does not affect priming of encephalitogenic Th cells in EAE. Eur J Immunol (2012) 42:2555-63. doi:10.1002/eji.201142239

49. Wlodarczyk A, Lobner M, Cedile O, Owens T. Comparison of microglia and infiltrating $\mathrm{CD} 11 \mathrm{c}(+)$ cells as antigen presenting cells for $\mathrm{T}$ cell proliferation and cytokine response. J Neuroinflammation (2014) 11:57. doi:10.1186/ 1742-2094-11-57

50. Sosa RA, Murphey C, Ji N, Cardona AE, Forsthuber TG. The kinetics of myelin antigen uptake by myeloid cells in the central nervous system during experimental autoimmune encephalomyelitis. J Immunol (2013) 191:5848-57. doi:10.4049/jimmunol.1300771

51. Goverman J, Brabb T, Paez A, Harrington C, von Dassow P. Initiation and regulation of CNS autoimmunity. Crit Rev Immunol (1997) 17:469-80.

52. Hawiger D, Masilamani RF, Bettelli E, Kuchroo VK, Nussenzweig MC. Immunological unresponsiveness characterized by increased expression of CD5 on peripheral T cells induced by dendritic cells in vivo. Immunity (2004) 20:695-705. doi:10.1016/j.immuni.2004.05.002

53. Ring S, Maas M, Nettelbeck DM, Enk AH, Mahnke K. Targeting of autoantigens to DEC205(+) dendritic cells in vivo suppresses experimental allergic encephalomyelitis in mice. J Immunol (2013) 191:2938-47. doi:10.4049/ jimmunol.1202592

54. Reboulet RA, Hennies CM, Garcia Z, Nierkens S, Janssen EM. Prolonged antigen storage endows merocytic dendritic cells with enhanced capacity to prime anti-tumor responses in tumor-bearing mice. J Immunol (2010) 185:3337-47. doi:10.4049/jimmunol.1001619

55. Pelletier AN, Lesage S. The Idd13 congenic interval defines the number of merocytic dendritic cells, a novel trait associated with autoimmune diabetes susceptibility. J Autoimmun (2013) 43:70-7. doi:10.1016/j.jaut.2013.04.004

56. Katz JD, Ondr JK, Opoka RJ, Garcia Z, Janssen EM. Cutting edge: merocytic dendritic cells break $\mathrm{T}$ cell tolerance to beta cell antigens in nonobese diabetic mouse diabetes. J Immunol (2010) 185:1999-2003. doi:10.4049/jimmunol. 1001398

57. Banchereau J, Pascual V. Type I interferon in systemic lupus erythematosus and other autoimmune diseases. Immunity (2006) 25:383-92. doi:10.1016/j. immuni.2006.08.010

58. Bailey-Bucktrout SL, Caulkins SC, Goings G, Fischer JA, Dzionek A, Miller SD. Cutting edge: central nervous system plasmacytoid dendritic cells regulate the severity of relapsing experimental autoimmune encephalomyelitis. J Immunol (2008) 180:6457-61. doi:10.4049/jimmunol.180.10.6457

59. Irla M, Kupfer N, Suter T, Lissilaa R, Benkhoucha M, Skupsky J, et al. MHC class II-restricted antigen presentation by plasmacytoid dendritic cells inhibits
T cell-mediated autoimmunity. J Exp Med (2010) 207:1891-905. doi:10.1084/ jem. 20092627

60. Xia CQ, Peng R, Chernatynskaya AV, Yuan L, Carter C, Valentine J, et al. Increased IFN-alpha-producing plasmacytoid dendritic cells (pDCs) in human Th1-mediated type 1 diabetes: pDCs augment Th1 responses through IFN-alpha production. J Immunol (2014) 193:1024-34. doi:10.4049/ jimmunol.1303230

61. Loschko J, Heink S, Hackl D, Dudziak D, Reindl W, Korn T, et al. Antigen targeting to plasmacytoid dendritic cells via Siglec-H inhibits Th cell-dependent autoimmunity. J Immunol (2011) 187:6346-56. doi:10.4049/ jimmunol.1102307

62. Loschko J, Schlitzer A, Dudziak D, Drexler I, Sandholzer N, Bourquin C, et al. Antigen delivery to plasmacytoid dendritic cells via BST2 induces protective T cell-mediated immunity. J Immunol (2011) 186:6718-25. doi:10.4049/ jimmunol.1004029

63. Blasius AL, Giurisato E, Cella M, Schreiber RD, Shaw AS, Colonna M. Bone marrow stromal cell antigen 2 is a specific marker of type I IFN-producing cells in the naive mouse, but a promiscuous cell surface antigen following IFN stimulation. J Immunol (2006) 177:3260-5. doi:10.4049/jimmunol.177.5.3260

64. Tarbell KV, Yamazaki S, Steinman RM. The interactions of dendritic cells with antigen-specific, regulatory $\mathrm{T}$ cells that suppress autoimmunity. Semin Immunol (2006) 18:93-102. doi:10.1016/j.smim.2006.01.009

65. Turner MS, Kane LP, Morel PA. Dominant role of antigen dose in CD4+Foxp3+ regulatory T cell induction and expansion. J Immunol (2009) 183:4895-903. doi:10.4049/jimmunol.0901459

66. Gregori S, Tomasoni D, Pacciani V, Scirpoli M, Battaglia M, Magnani CF, et al. Differentiation of type $1 \mathrm{~T}$ regulatory cells $(\mathrm{Tr} 1)$ by tolerogenic $\mathrm{DC}-10$ requires the IL-10-dependent ILT4/HLA-G pathway. Blood (2010) 116:935-44. doi:10. 1182/blood-2009-07-234872

67. Scroggins SM, Olivier AK, Meyerholz DK, Schlueter AJ. Characterization of regulatory dendritic cells that mitigate acute graft-versus-host disease in older mice following allogeneic bone marrow transplantation. PLoS One (2013) 8:e75158. doi:10.1371/journal.pone. 0075158

68. Bacchetta R, Gregori S, Serafini G, Sartirana C, Schulz U, Zino E, et al. Molecular and functional characterization of allogantigen-specific anergic $\mathrm{T}$ cells suitable for cell therapy. Haematologica (2010) 95:2134-43. doi:10.3324/ haematol.2010.025825

69. Wu L, D’Amico A, Hochrein H, O’Keeffe M, Shortman K, Lucas K. Development of thymic and splenic dendritic cell populations from different hemopoietic precursors. Blood (2001) 98:3376-82. doi:10.1182/blood.V98.12.3376

70. Ji Q, Castelli L, Goverman JM. MHC class I-restricted myelin epitopes are cross-presented by Tip-DCs that promote determinant spreading to CD8(+) T cells. Nat Immunol (2013) 14:254-61. doi:10.1038/ni.2513

71. Nakano H, Lin KL, Yanagita M, Charbonneau C, Cook DN, Kakiuchi T, et al. Blood-derived inflammatory dendritic cells in lymph nodes stimulate acute T helper type 1 immune responses. Nat Immunol (2009) 10:394-402. doi:10.1038/ni.1707

72. Maraskovsky E, Brasel K, Teepe M, Roux ER, Lyman SD, Shortman K, et al. Dramatic increase in the numbers of functionally mature dendritic cells in Flt3 ligand-treated mice: multiple dendritic cell subpopulations identified. J Exp Med (1996) 184:1953-62. doi:10.1084/jem.184.5.1953

73. Anandasabapathy N, Feder R, Mollah S, Tse SW, Longhi MP, Mehandru S, et al. Classical Flt3L-dependent dendritic cells control immunity to protein vaccine. J Exp Med (2014) 211:1875-91. doi:10.1084/jem.20131397

74. Van Belle TL, Juntti T, Liao J, von Herrath MG. Pre-existing autoimmunity determines type 1 diabetes outcome after Flt3-ligand treatment. J Autoimmun (2010) 34:445-52. doi:10.1016/j.jaut.2009.11.010

75. Vasquez AC, Feili-Hariri M, Tan RJ, Morel PA. Qualitative and quantitative abnormalities in splenic dendritic cell populations in NOD mice. Clin Exp Immunol (2004) 135:209-18. doi:10.1111/j.1365-2249.2003.02359.x

76. Chilton PM, Rezzoug F, Fugier-Vivier I, Weeter LA, Xu H, Huang Y, et al. Flt3-ligand treatment prevents diabetes in NOD mice. Diabetes (2004) 53:1995-2002. doi:10.2337/diabetes.53.8.1995

77. Ferris ST, Carrero JA, Mohan JF, Calderon B, Murphy KM, Unanue ER. A minor subset of Batf3-dependent antigen-presenting cells in islets of Langerhans is essential for the development of autoimmune diabetes. Immunity (2014) 41:657-69. doi:10.1016/j.immuni.2014.09.012

78. Hildner K, Edelson BT, Purtha WE, Diamond M, Matsushita H, Kohyama M, et al. Batf3 deficiency reveals a critical role for CD8alpha+ dendritic cells in 
cytotoxic T cell immunity. Science (2008) 322:1097-100. doi:10.1126/science. 1164206

79. Yamanouchi J, Rainbow D, Serra P, Howlett S, Hunter K, Garner VE, et al. Interleukin-2 gene variation impairs regulatory $\mathrm{T}$ cell function and causes autoimmunity. Nat Genet (2007) 39:329-37. doi:10.1038/ng1958

80. Lau-Kilby AW, Kretz CC, Pechhold S, Price JD, Dorta S, Ramos H, et al. Interleukin-2 inhibits FMS-like tyrosine kinase 3 receptor ligand (flt3L)dependent development and function of conventional and plasmacytoid dendritic cells. Proc Natl Acad Sci U S A (2011) 108:2408-13. doi:10.1073/pnas. 1009738108

81. Todd JA, Acha-Orbea H, Bell JI, Chao N, Fronek Z, Jacob CO, et al. A molecular basis for MHC class II - associated autoimmunity. Science (1988) 240:1003-9. doi:10.1126/science.3368786

82. Theofilopoulos AN, Baccala R, Beutler B, Kono DH. Type I interferons (alpha/beta) in immunity and autoimmunity. Annu Rev Immunol (2005) 23:307-36. doi:10.1146/annurev.immunol.23.021704.115843

83. Kaneko T, Saito Y, Kotani T, Okazawa H, Iwamura H, Sato-Hashimoto M, et al. Dendritic cell-specific ablation of the protein tyrosine phosphatase Shp1 promotes Th1 cell differentiation and induces autoimmunity. J Immunol (2012) 188:5397-407. doi:10.4049/jimmunol.1103210

84. Hammer GE, Turer EE, Taylor KE, Fang CJ, Advincula R, Oshima S, et al. Expression of A20 by dendritic cells preserves immune homeostasis and prevents colitis and spondyloarthritis. Nat Immunol (2011) 12:1184-93. doi:10. 1038/ni.2135

85. Abram CL, Roberge GL, Pao LI, Neel BG, Lowell CA. Distinct roles for neutrophils and dendritic cells in inflammation and autoimmunity in motheaten mice. Immunity (2013) 38:489-501. doi:10.1016/j.immuni.2013.02.018

86. Kim SJ, Zou YR, Goldstein J, Reizis B, Diamond B. Tolerogenic function of Blimp-1 in dendritic cells. J Exp Med (2011) 208:2193-9. doi:10.1084/jem. 20110658

87. Stranges PB, Watson J, Cooper CJ, Choisy-Rossi CM, Stonebraker AC, Beighton RA, et al. Elimination of antigen-presenting cells and autoreactive $\mathrm{T}$ cells by Fas contributes to prevention of autoimmunity. Immunity (2007) 26:629-41. doi:10.1016/j.immuni.2007.03.016

88. Yang H, Qiu Q, Gao B, Kong S, Lin Z, Fang D. Hrd1-mediated BLIMP1 ubiquitination promotes dendritic cell MHCII expression for CD4 T cell priming during inflammation. J Exp Med (2014) 211:2467-79. doi:10.1084/ jem.20140283

89. Wang Y, Shaked I, Stanford SM, Zhou W, Curtsinger JM, Mikulski Z, et al. The autoimmunity-associated gene PTPN22 potentiates toll-like receptor-driven, type 1 interferon-dependent immunity. Immunity (2013) 39:111-22. doi:10. 1016/j.immuni.2013.06.013

90. Ivakine EA, Gulban OM, Mortin-Toth SM, Wankiewicz E, Scott C, Spurrell D, et al. Molecular genetic analysis of the Idd4 locus implicates the IFN response in type 1 diabetes susceptibility in nonobese diabetic mice. J Immunol (2006) 176:2976-90. doi:10.4049/jimmunol.176.5.2976

91. Hamilton-Williams EE, Martinez X, Clark J, Howlett S, Hunter KM, Rainbow DB, et al. Expression of diabetes-associated genes by dendritic cells and CD4 T cells drives the loss of tolerance in nonobese diabetic mice. J Immunol (2009) 183:1533-41. doi:10.4049/jimmunol.0900428

92. Hamilton-Williams EE, Cheung J, Rainbow DB, Hunter KM, Wicker LS, Sherman LA. Cellular mechanisms of restored beta-cell tolerance mediated by protective alleles of Idd3 and Idd5. Diabetes (2012) 61:166-74. doi:10.2337/ db11-0790

93. Asano K, Ikegami H, Fujisawa T, Nishino M, Nojima K, Kawabata Y, et al. Molecular scanning of interleukin-21 gene and genetic susceptibility to type 1 diabetes. Hum Immunol (2007) 68:384-91. doi:10.1016/j.humimm.2007.01. 009

94. Van Belle TL, Nierkens S, Arens R, von Herrath MG. Interleukin-21 receptormediated signals control autoreactive $\mathrm{T}$ cell infiltration in pancreatic islets. Immunity (2012) 36:1060-72. doi:10.1016/j.immuni.2012.04.005

95. Gulden E, Wen L. Toll-like receptor activation in immunity vs. tolerance in autoimmune diabetes. Front Immunol (2014) 5:119. doi:10.3389/fimmu.2014. 00119

96. Morel PA. Dendritic cell subsets in type 1 diabetes: friend or foe? Front Immunol (2013) 4:415. doi:10.3389/fimmu.2013.00415

97. Carrero JA, Calderon B, Towfic F, Artyomov MN, Unanue ER. Defining the transcriptional and cellular landscape of type 1 diabetes in the NOD mouse. PLoS One (2013) 8:e59701. doi:10.1371/journal.pone.0059701
98. Ghaemi Oskouie F, Shameli A, Yang A, Desrosiers MD, Mucsi AD, Blackburn MR, et al. High levels of adenosine deaminase on dendritic cells promote autoreactive $\mathrm{T}$ cell activation and diabetes in nonobese diabetic mice. J Immunol (2011) 186:6798-806. doi:10.4049/jimmunol.1004222

99. Poligone B, Weaver DJ Jr, Sen P, Baldwin AS Jr, Tisch R. Elevated NF-kappaB activation in nonobese diabetic mouse dendritic cells results in enhanced APC function. J Immunol (2002) 168:188-96. doi:10.4049/jimmunol.168.1.188

100. Lee LF, Xu B, Michie SA, Beilhack GF, Warganich T, Turley S, et al. The role of TNF-alpha in the pathogenesis of type 1 diabetes in the nonobese diabetic mouse: analysis of dendritic cell maturation. Proc Natl Acad Sci U S A (2005) 102:15995-6000. doi:10.1073/pnas.0508122102

101. Yen JH, Ganea D. Interferon beta induces mature dendritic cell apoptosis through caspase-11/caspase-3 activation. Blood (2009) 114:1344-54. doi:10. 1182/blood-2008-12-196592

102. Bartholome EJ, Willems F, Crusiaux A, Thielemans K, Schandene L, Goldman $\mathrm{M}$. Interferon-beta inhibits Th1 responses at the dendritic cell level. Relevance to multiple sclerosis. Acta Neurol Belg (1999) 99:44-52.

103. Chaussabel D, Quinn C, Shen J, Patel P, Glaser C, Baldwin N, et al. A modular analysis framework for blood genomics studies: application to systemic lupus erythematosus. Immunity (2008) 29:150-64. doi:10.1016/j. immuni.2008.05.012

104. Chen YG, Cabrera SM, Jia S, Kaldunski ML, Kramer J, Cheong S, et al. Molecular signatures differentiate immune states in type 1 diabetic families. Diabetes (2014) 63:3960-73. doi:10.2337/db14-0214

105. Bourges D, Ross EM, Allen S, Read S, Houghton FJ, Bedoui S, et al. Transient systemic inflammation does not alter the induction of tolerance to gastric autoantigens by migratory dendritic cells. J Immunol (2014) 192:5023-30. doi:10.4049/jimmunol.1303429

106. Belkaid Y, Hand TW. Role of the microbiota in immunity and inflammation Cell (2014) 157:121-41. doi:10.1016/j.cell.2014.03.011

107. Hu C, Wong FS, Wen L. Type 1 diabetes and gut microbiota: friend or foe? Pharmacol Res (2015). doi:10.1016/j.phrs.2015.02.006

108. Kostic AD, Gevers D, Siljander H, Vatanen T, Hyotylainen T, Hamalainen AM, et al. The dynamics of the human infant gut microbiome in development and in progression toward type 1 diabetes. Cell Host Microbe (2015) 17:260-73. doi:10.1016/j.chom.2015.01.001

109. Dunne JL, Triplett EW, Gevers D, Xavier R, Insel R, Danska J, et al. The intestinal microbiome in type 1 diabetes. Clin Exp Immunol (2014) 177:30-7. doi:10.1111/cei.12321

110. Wu HJ, Ivanov II, Darce J, Hattori K, Shima T, Umesaki Y, et al. Gut-residing segmented filamentous bacteria drive autoimmune arthritis via T helper 17 cells. Immunity (2010) 32:815-27. doi:10.1016/j.immuni.2010.06.001

111. Kriegel MA, Sefik E, Hill JA, Wu HJ, Benoist C, Mathis D. Naturally transmitted segmented filamentous bacteria segregate with diabetes protection in nonobese diabetic mice. Proc Natl Acad Sci U S A (2011) 108:11548-53. doi:10.1073/pnas.1108924108

112. Berer K, Mues M, Koutrolos M, Rasbi ZA, Boziki M, Johner C, et al. Commensal microbiota and myelin autoantigen cooperate to trigger autoimmune demyelination. Nature (2011) 479:538-41. doi:10.1038/nature10554

113. Yurkovetskiy L, Burrows M, Khan AA, Graham L, Volchkov P, Becker L, et al. Gender bias in autoimmunity is influenced by microbiota. Immunity (2013) 39:400-12. doi:10.1016/j.immuni.2013.08.013

114. Markle JG, Frank DN, Mortin-Toth S, Robertson CE, Feazel LM, RolleKampczyk U, et al. Sex differences in the gut microbiome drive hormonedependent regulation of autoimmunity. Science (2013) 339:1084-8. doi:10. $1126 /$ science. 1233521

115. Ivanov II, Atarashi K, Manel N, Brodie EL, Shima T, Karaoz U, et al. Induction of intestinal Th17 cells by segmented filamentous bacteria. Cell (2009) 139:485-98. doi:10.1016/j.cell.2009.09.033

116. Aumeunier A, Grela F, Ramadan A, Pham Van L, Bardel E, Gomez Alcala A, et al. Systemic Toll-like receptor stimulation suppresses experimental allergic asthma and autoimmune diabetes in NOD mice. PLoS One (2010) 5:e11484. doi:10.1371/journal.pone.0011484

117. Tai N, Wong FS, Wen L. TLR9 deficiency promotes CD73 expression in $\mathrm{T}$ cells and diabetes protection in nonobese diabetic mice. J Immunol (2013) 191:2926-37. doi:10.4049/jimmunol.1300547

118. Prinz M, Garbe F, Schmidt H, Mildner A, Gutcher I, Wolter K, et al. Innate immunity mediated by TLR9 modulates pathogenicity in an animal model of multiple sclerosis. J Clin Invest (2006) 116:456-64. doi:10.1172/JCI26078 
119. Gulden E, Ihira M, Ohashi A, Reinbeck AL, Freudenberg MA, Kolb H, et al. Toll-like receptor 4 deficiency accelerates the development of insulin-deficient diabetes in non-obese diabetic mice. PLoS One (2013) 8:e75385. doi:10.1371/ journal.pone.0075385

120. Bour-Jordan H, Salomon BL, Thompson HL, Szot GL, Bernhard MR, Bluestone JA. Costimulation controls diabetes by altering the balance of pathogenic and regulatory T cells. J Clin Invest (2004) 114:979-87. doi:10. 1172/JCI200420483

121. Martin S, Agarwal R, Murugaiyan G, Saha B. CD40 expression levels modulate regulatory $\mathrm{T}$ cells in Leishmania donovani infection. J Immunol (2010) 185:551-9. doi:10.4049/jimmunol.0902206

122. Richer MJ, Straka N, Fang D, Shanina I, Horwitz MS. Regulatory T-cells protect from type 1 diabetes after induction by coxsackievirus infection in the context of transforming growth factor-beta. Diabetes (2008) 57:1302-11. doi:10.2337/db07-1460

123. Richer MJ, Lavallee DJ, Shanina I, Horwitz MS. Immunomodulation of antigen presenting cells promotes natural regulatory $\mathrm{T}$ cells that prevent autoimmune diabetes in NOD mice. PLoS One (2012) 7:e31153. doi:10.1371/journal.pone. 0031153

124. Akdis M, Palomares O, van de Veen W, van Splunter M, Akdis CA. TH17 and TH22 cells: a confusion of antimicrobial response with tissue inflammation versus protection. J Allergy Clin Immunol (2012) 129(1438-49):quiz50-1. doi:10.1016/j.jaci.2012.05.003

125. Saeki Y, Ishihara K. Infection-immunity liaison: pathogen-driven autoimmune-mimicry (PDAIM). Autoimmun Rev (2014) 13:1064-9. doi:10.1016/j.autrev.2014.08.024

126. Gallo PM, Gallucci S. The dendritic cell response to classic, emerging, and homeostatic danger signals. Implications for autoimmunity. Front Immunol (2013) 4:138. doi:10.3389/fimmu.2013.00138

127. Soares H, Waechter H, Glaichenhaus N, Mougneau E, Yagita H, Mizenina O, et al. A subset of dendritic cells induces CD4+ T cells to produce IFN-gamma by an IL-12-independent but CD70-dependent mechanism in vivo. J Exp Med (2007) 204:1095-106. doi:10.1084/jem.20070176

128. Kim TS, Gorski SA, Hahn S, Murphy KM, Braciale TJ. Distinct dendritic cell subsets dictate the fate decision between effector and memory CD8(+) $\mathrm{T}$ cell differentiation by a CD24-dependent mechanism. Immunity (2014) 40:400-13. doi:10.1016/j.immuni.2014.02.004

129. Boscardin SB, Hafalla JC, Masilamani RF, Kamphorst AO, Zebroski HA, Rai $\mathrm{U}$, et al. Antigen targeting to dendritic cells elicits long-lived $\mathrm{T}$ cell help for antibody responses. J Exp Med (2006) 203:599-606. doi:10.1084/jem. 20051639

130. Wang B, Zaidi N, He LZ, Zhang L, Kuroiwa JM, Keler T, et al. Targeting of the non-mutated tumor antigen HER2/neu to mature dendritic cells induces an integrated immune response that protects against breast cancer in mice. Breast Cancer Res (2012) 14:R39. doi:10.1186/bcr3135

131. Neubert K, Lehmann CH, Heger L, Baranska A, Staedtler AM, Buchholz $\mathrm{VR}$, et al. Antigen delivery to CD11c+CD8- dendritic cells induces protective immune responses against experimental melanoma in mice in vivo. J Immunol (2014) 192:5830-8. doi:10.4049/jimmunol.1300975

132. Takaki H, Oshiumi H, Matsumoto M, Seya T. Dendritic cell subsets involved in type I IFN induction in mouse measles virus infection models. Int J Biochem Cell Biol (2014) 53C:329-33. doi:10.1016/j.biocel.2014.05.001

133. Gupta MR, Kolli D, Molteni C, Casola A, Garofalo RP. Paramyxovirus infection regulates $\mathrm{T}$ cell responses by BDCA-1+ and BDCA-3+ myeloid dendritic cells. PLoS One (2014) 9:e99227. doi:10.1371/journal. pone.0099227

134. Herold KC, Vignali DA, Cooke A, Bluestone JA. Type 1 diabetes: translating mechanistic observations into effective clinical outcomes. Nat Rev Immunol (2013) 13:243-56. doi:10.1038/nri3422
135. Balasa B, Krahl T, Patstone G, Lee J, Tisch R, McDevitt HO, et al. CD40 ligandCD40 interactions are necessary for the initiation of insulitis and diabetes in nonobese diabetic mice. J Immunol (1997) 159:4620-7.

136. Lenschow DJ, Ho SC, Sattar H, Rhee L, Gray G, Nabavi N, et al. Differential effects of anti-B7-1 and anti-B7-2 monoclonal antibody treatment on the development of diabetes in the nonobese diabetic mouse. J Exp Med (1995) 181:1145-55. doi:10.1084/jem.181.3.1145

137. Orban T, Bundy B, Becker DJ, DiMeglio LA, Gitelman SE, Goland R, et al. Co-stimulation modulation with abatacept in patients with recent-onset type 1 diabetes: a randomised, double-blind, placebo-controlled trial. Lancet (2011) 378:412-9. doi:10.1016/S0140-6736(11)60886-6

138. Orban T, Bundy B, Becker DJ, Dimeglio LA, Gitelman SE, Goland R, et al. Costimulation modulation with abatacept in patients with recent-onset type 1 diabetes: follow-up 1 year after cessation of treatment. Diabetes Care (2014) 37:1069-75. doi:10.2337/dc13-0604

139. Bresson D, Fousteri G, Manenkova Y, Croft M, von Herrath M. Antigenspecific prevention of type 1 diabetes in NOD mice is ameliorated by OX40 agonist treatment. J Autoimmun (2011) 37:342-51. doi:10.1016/j.jaut. 2011.10.001

140. Pakala SV, Bansal-Pakala P, Halteman BS, Croft M. Prevention of diabetes in NOD mice at a late stage by targeting OX40/OX40 ligand interactions. Eur J Immunol (2004) 34:3039-46. doi:10.1002/eji.200425141

141. Kalunian KC, Davis JC Jr, Merrill JT, Totoritis MC, Wofsy D. Treatment of systemic lupus erythematosus by inhibition of T cell costimulation with antiCD154: a randomized, double-blind, placebo-controlled trial. Arthritis Rheum (2002) 46:3251-8. doi:10.1002/art.10681

142. Merrill JT, Burgos-Vargas R, Westhovens R, Chalmers A, D'Cruz D, Wallace DJ, et al. The efficacy and safety of abatacept in patients with non-lifethreatening manifestations of systemic lupus erythematosus: results of a twelve-month, multicenter, exploratory, phase IIb, randomized, double-blind, placebo-controlled trial. Arthritis Rheum (2010) 62:3077-87. doi:10.1002/art. 27601

143. Furie R, Nicholls K, Cheng TT, Houssiau F, Burgos-Vargas R, Chen SL, et al. Efficacy and safety of abatacept in lupus nephritis: a twelve-month, randomized, double-blind study. Arthritis Rheumatol (2014) 66:379-89. doi:10.1002/ art. 38260

144. Mastrandrea L, Yu J, Behrens T, Buchlis J, Albini C, Fourtner S, et al. Etanercept treatment in children with new-onset type 1 diabetes: pilot randomized, placebo-controlled, double-blind study. Diabetes Care (2009) 32:1244-9. doi: $10.2337 / \mathrm{dc} 09-1571$

145. Timper K, Hruz P, Beglinger C, Donath MY. Infliximab in the treatment of Crohn disease and type 1 diabetes. Diabetes Care (2013) 36:e90-1. doi:10.2337/ dc13-0199

146. Shoda LK, Young DL, Ramanujan S, Whiting CC, Atkinson MA, Bluestone JA, et al. A comprehensive review of interventions in the NOD mouse and implications for translation. Immunity (2005) 23:115-26. doi:10.1016/j.immuni.2005 08.002

Conflict of Interest Statement: The authors declare that the research was conducted in the absence of any commercial or financial relationships that could be construed as a potential conflict of interest.

Copyright (C) 2015 Price and Tarbell. This is an open-access article distributed under the terms of the Creative Commons Attribution License (CC BY). The use, distribution or reproduction in other forums is permitted, provided the original author(s) or licensor are credited and that the original publication in this journal is cited, in accordance with accepted academic practice. No use, distribution or reproduction is permitted which does not comply with these terms. 